\title{
Assessment of the Level of Knowledge of Climate Change of Undergraduate Science and Agriculture Students
}

\author{
Nabeel M. Gazzaz ${ }^{1, *} \&$ Bassam A. Aldeseet ${ }^{2}$ \\ ${ }^{1}$ Department of Climate Change and Sustainable Agriculture, Faculty of Agriculture and Science, Jarash University, \\ Jarash, Jordan \\ ${ }^{2}$ Department of Agricultural Economics and Extention, Faculty of Agriculture and Science, Jarash University, Jarash, \\ Jordan \\ *Correspondence: Department of Climate Change and Sustainable Agriculture, Faculty of Agriculture and Science, \\ Jarash University, Rashadeyyah, Jarash, 26150, Jordan. Tel: 962-78-079-0891. E-mail: N.Gazzaz@jpu.edu.jo
}

Received: August 1, 2021

Accepted: September 5, $2021 \quad$ Online Published: October 12, 2021

doi:10.5430/wje.v11n5p41

URL: https://doi.org/10.5430/wje.v11n5p41

\begin{abstract}
Introduction of climate change (CC) courses in universities is critical for helping future generations and leaders in recognizing the global challenges of $\mathrm{CC}$ and finding ways for adapting with it. People's knowledge of CC can influence success of any planned CC mitigation and adaptation programs and activities. Thereupon, it is vital for environmental planners and researchers to conduct regular assessments of this knowledge to determine need for curriculum reform, if any. This study was conducted to assess the level of CC knowledge of undergraduate physical science and agricultural science students in Jarash University, Jordan. The study used specifically-designed Climate Change Knowledge Test (CCKT) as the data collection tool. Population of the study was undergraduate science and agriculture students enrolled in the Faculty of Agriculture and Science. The study sample consisted of 285 students, comprising 103 science students and 182 agriculture students. The results indicate that the sample students have high levels of knowledge of the nature, causes, and effects of CC. However, on the average, a higher number of the sample students posses knowledge of effects of CC $(n=223, \%=79.3 \%)$ than its nature $(209,73.5 \%)$ and causes $(190,66.9 \%)$. Additionally, it was found that the female students have higher levels of overall CC knowledge than their male peers and that the agriculture students possess higher levels of CC knowledge than their science peers. These results emphasize the need for curriculum review and reform to ensure equipping the university graduates with comprehensive knowledge of CC.
\end{abstract}

Keywords: climate change, knowledge, nature, causes, effects, undergraduate students

\section{Introduction}

\subsection{Definition of Climate Change}

Climate is commonly described as the average weather, where weather is state of the atmosphere at a specific point of time (Frigg, Thompson, \& Wernd, 2015). The National Academies (2008) defined climate as "the long-term average of weather conditions, such as temperature, cloudiness, and precipitation" and clarified that "trends in these conditions for decades or longer are a primary measure of climate change." However, Hulme et al. (2009) defined climate as measurement of the average and the variability of appropriate quantities of specific variables (e.g., precipitation, wind direction, wind speed, and temperature) over a certain period of time. In this context, the traditional period for averaging of the weather variables is 30 years (Hulme et al., 2009; Koutsoyiannis, 2021).

Numerous definitions of climate change (CC) can be found in the literature. As an example, Lineman et al. (2015) defined it as "a change in global or regional climate patterns, in particular a change apparent from the mid to late $20^{\text {th }}$ century onwards and attributed to the increased levels of atmospheric carbon dioxide arising from the use of fossil fuels" (Lineman et al., 2015, p. 3). Earlier, the United Nations Framework Convention on Climate Change (UNFCCC) defined Climate Change as "a change of climate which is attributed directly or indirectly to human activity that alters the composition of the global atmosphere and which is in addition to natural climate variability 
observed over comparable time periods" (UNFCCC, 1992, p. 3).

Lineman et al.'s (2015) definition of CC ascribes it almost exclusively to human activities (mainly fossil fuel burning) while the UNFCCC's (1992) definition pinpoints the role of natural climate variability in the contemporary CC. However, the natural processes have little contribution to $\mathrm{CC}$ while the human activities are the largest contributor to it (Sulistyawati, Mulasari, \& Sukesi, 2018). Within this context, Crowley (2000) spotlighted that observations for the past 1,000 years support the conclusion that natural variability plays secondary role in the twentieth-century global warming and that most of the reported warming is a result of anthropogenic increases in greenhouse gas (GHG) concentrations in the atmosphere. He mentioned that the joint effects of volcanism and solar variability could have contributed $0.15-0.2{ }^{\circ} \mathrm{C}$ to the increase in temperature in the period $1905-1955$, but only nearly one-quarter to the total twentieth-century warming. In harmony with this, Baer et al. (2019) stressed that CC is a phenomenon that is mostly caused by human activity and is associated with the growing emission of GHGs to the atmosphere. Thereupon, the researchers focus in this paper more on human activities than on natural variability as the principal cause of CC.

\subsection{Causes of Climate Change}

Climate change is traced back to varying natural and anthropogenic causes. Odjugo (2010) and Falaye and Okwilagwe (2016) underscored that CC is caused by two factors: (i) bio-geographic factors, which encompass natural forces, and (ii) anthropogenic factors, which are factors that are linked with human activities. The latter factors encircle (i) the emission of large quantities of GHGs into the atmosphere through, for example, fossil fuel burning, gas flaring, industrialization, biomass burning, animal farming, and solid waste incineration; and (ii) the human activities which reduce the amount of carbon that is absorbed from the atmosphere like deforestation (Akrofi, Antwi, \& Gumbo, 2019; Odjugo, 2010; Yang et al., 2018). The emitted GHGs are the major culprit for global warming (Crowley, 2000; Hulme et al., 2009). Corollary to this, Crowley (2000) and Frigg, Thompson, and Wernd (2015) emphasized the finding that the temperature increase in the late $20^{\text {th }}$ century was caused primarily by GHG forcing and that, accordingly, our trust in that the GHGs explain the global warming is quite high. These gases mainly include carbon dioxide $\left(\mathrm{CO}_{2}\right)$, methane $\left(\mathrm{CH}_{4}\right)$, ammonia $\left(\mathrm{NH}_{3}\right)$, nitrous oxide $\left(\mathrm{N}_{2} \mathrm{O}\right)$, chlorofluorocarbons (CFCs), and sulfur hexafluoride ( $\left.\mathrm{SF}_{6}\right)$ (Agboola \& Emmanuel, 2016; Odjugo, 2010). Carbon dioxide is the particular GHG emitted at the highest quantities, followed by $\mathrm{CH}_{4}$, the CFCs, and $\mathrm{N}_{2} \mathrm{O}$ (Odjugo, 2010).

\subsection{Effects of Climate Change}

Varying effects of CC have been reported in the literature. These encircle melting of glaciers (Ojomo et al., 2015), sea level rise (Akrofi, Antwi, \& Gumbo, 2019; Marty \& Yokochi, 2006; Ojomo et al., 2015; Olaniyi, Olutimehin, \& Funmilayo, 2019), desertification (Ojomo et al., 2015), coastal erosion (Ojomo et al., 2015; Olaniyi, Olutimehin, \& Funmilayo, 2019), increasing frequency and intensity of extreme weather conditions (e.g., heat waves, drought, flooding, hurricanes, cyclones, and tornadoes (Akrofi, Antwi, \& Gumbo, 2019; Akter \& Bennett, 2011; Ojomo et al., 2015; Olaniyi, Olutimehin, \& Funmilayo, 2019)), changes in rainfall patterns (Marty \& Yokochi, 2006), and water scarcity and shortages (Akter \& Bennett, 2011; Antwi \& Gumbo, 2019; Marty \& Yokochi, 2006). As far as agriculture in particular is concerned, negative impacts of $\mathrm{CC}$ include proliferation of insect attacks and diseases of crops (Dhanya \& Ramachandran, 2016; Olaniyi, Olutimehin, \& Funmilayo, 2019); species extinction and biodiversity loss (Akrofi, Antwi, \& Gumbo, 2019; Olaniyi, Olutimehin, \& Funmilayo, 2019); reduction in the area under cultivation (Dhanya \& Ramachandran, 2016); crop damage (Dhanya \& Ramachandran, 2016); crop loss (Dhanya \& Ramachandran, 2016); and low crop yields and, thereupon, reduced agricultural production (Akrofi, Antwi, \& Gumbo 2019; Akter \& Bennett, 2011; Marty \& Yokochi, 2006). In other respects, there are growing concerns about the negative effects of $\mathrm{CC}$ on human health and wellbeing. However, such effects are beyond the scope of this study. The interested reader can find good coverage of this topic in the works of Haines and Ebi (2019), Kabir et al. (2016), Nigatu, Asamoah, and Kloos (2014), Ogden (2017), Sulistyawati, Mulasari, and Sukesi (2018), amongst others.

\subsection{Climate Change Knowledge Research: Briefing}

Review of the literature reveals that knowledge about $\mathrm{CC}$ has been approached from varying perspectives, mainly including general knowledge of CC (e.g., Barimah et al., 2012; David, 2015; Orlove et al., 2010; Sundblad, Biel, \& Gärling, 2009); knowledge of causes and/or effects of CC (e.g., Dal, Ozturk, \& Alper, 2014; Oruonye, 2011; Yang et al., 2018); and knowledge of health impacts of CC (e.g., Kabir et al., 2016; Nigatu, Asamoah, \& Kloos, 2014; Sulistyawati, Mulasari, \& Sukesi, 2018). Many other issues related to CC have been studied as well, including awareness and/or perception of CC (e.g., Barreda, 2018; Jamshidi et al., 2018; Ochieng \& Koske, 2013; Rahman et al., 2014;); awareness of CC risk (e.g., Etkin \& Ho, 2009; Shukla et al., 2019; Sullivan \& White, 2009; Xie et al., 
2019); and climate change-associated attitudes, behaviors, and practices (e.g., Christensen \& Knezek, 2015; Jamshidi et al., 2018; Rahman et al., 2021; Wei et al., 2014).

In other respects, it is noticed that previous CC knowledge studies were performed in a wide spectrum of countries, including America (e.g., Christensen \& Knezek, 2015; Sullivan \& White, 2009); Australia (e.g., Akter \& Bennett, 2011; Xie et al., 2019); Banglasesh (e.g., Kabir et al., 2016; Rahman et al., 2014); China (e.g., Wei et al., 2014; Yang et al., 2018); Denmark (e.g., Jørgensen \& Termansen, 2016); Germany (e.g., Barkmann, Siebert, \& Lange, 2017); Ghana (e.g., Barimah, Kwadwo, \& David, 2015); India (e.g., Dhanya \& Ramachandran, 2016; Shukla et al., 2019); Indonesia (e.g., Sulistyawati, Mulasari, \& Sukesi, 2018); Iran (e.g., Jamshidi et al., 2018); Kenya (e.g., Ochieng \& Koske, 2013); Nigeria (e.g., Oruonye, 2011; Falaye \& Okwilagwe, 2016); Sweden (e.g., Sundblad, Biel, \& Gärling, 2009); Switzerland (e.g., Tobler, Visschers, \& Siegrist, 2012); Thailand (e.g., Rahman et al., 2021); The Philippines (e.g., Barreda, 2018); and Turkey (e.g., Dal, Ozturk, \& Alper, 2014; Tuna, Incekara, \& Tunç, 2011).

The target populations of previous CC knowledge studies varied broadly and included the general public (e.g., Barimah, Kwadwo, \& David, 2015; Kabir et al., 2016; Xie et al., 2019); farmers (e.g., Dhanya \& Ramachandran, 2016; Jørgensen \& Termansen, 2016; Shukla et al., 2019); healthcare professionals (e.g., La Torre et al., 2020; Nigatu, Asamoah, \& Kloos, 2014; Wei et al., 2014); school students (e.g., Falaye \& Okwilagwe, 2016; Rahman et al., 2014; Sulistyawati, Mulasari, \& Sukesi, 2018; Tuna, Incekara, \& Tunç, 2011); and university students (e.g., Agboola \& Emmanuel, 2016; Akrofi, Antwi, \& Gumbo, 2019; Barreda, 2018; Oruonye, 2011; Yang et al., 2018).

\subsection{Research Problem}

The foregoing three literature review paragraphs highlight lack of Arab studies of knowledge about CC, neither amongst university students, nor among any other population, whether in Jordan or in any other Arab country. In addition to this, the review uncovers limited investigation of CC knowledge among undergraduate university students worldwide. Within this context, previous studies underline that adequate sound knowledge about the nature, causes, and effects of CC is critical determinant of personal engagement in CC mitigation and adaptation efforts (Bord et al., 2000; Lorenzoni et al., 2007). Tobbler et al. (2012) maintain that lack of such knowledge may contribute to feeling of uncertainty about $\mathrm{CC}$, which may ultimately lead to skepticism about its reality, human's role in it, human's influence on it, and the need for quick responsible action. Since university students are anticipated to be the education and policy leaders of the future, the lack of reasonably sufficient sound knowledge about CC among them may affect their attitudes to $\mathrm{CC}$ and willingness to act responsibly and to support $\mathrm{CC}$ mitigation and adaptation policies and practices.

In accordance with the foregoing paragraph, and as underscored by Oruonye (2011), to be able to effectively adapt to $\mathrm{CC}$, there is a need for understanding the level of tertiary institution students' knowledge of this problem, especially its causes and effects. Hence, it is of paramount importance to investigate what the undergraduate students presently know about CC. To the researchers' best of knowledge, this investigation is the first local study that employs a representative sample of undergraduate students of physical sciences and agricultural sciences and addresses the nature, causes, and effects of $\mathrm{CC}$ using a knowledge test. The study is intended to extend our knowledge of this subject matter over a number of key issues related to CC knowledge among university students: (i) do the undergraduate science and agriculture students really know what climate change is? (ii) Do they know its main causes? And (iii) Do they know its major effects?

The results of this study can be useful for future physical science and agricultural science university students, agriculture practitioners, and the farmers in incorporating climate-friendly behaviors and practices in their every-day activities. As well, they can be of particular relevance for university faculty members and educators to identify gaps in current $\mathrm{CC}$ and related curricula and work on bridging them. This will, eventually, bring about improvement in responsiveness of the university graduates to the initiatives that aim at mitigating $\mathrm{CC}$ and adapting to it.

The rest of this paper is organized in three sections. Section 2 discusses the research method. It describes the study population and sample, knowledge test design and development, and data collection and analysis. Section 3, then, presents the main findings and discusses them. Thereafter, Section 4 presents the main conclusions drawn from the results of this study.

\section{Method}

\subsection{Participants}

This study is a quantitative cross-sectional survey of undergraduate students' knowledge of CC. The population of 
the study was undergraduate physical science and agricultural science students enrolled in the Faculty of Agriculture and Science (FAS) in Jarash University, Jordan. The faculty consists of two major departments, with four sections, each: (i) Department of Physical Sciences (DPSs (Biology, Chemistry, Mathematics, and Physics)) and (ii) Department of Agricultural Sciences (DASs (Plant Production and Protection, Animal Production and Protection, Food and Nutrition Science, and Agricultural Economics and Extension)). In the time being, the total number of students enrolled in the FAS is 1096 students, comprising 396 physical science students and 700 agricultural science students. This study population was selected based on their potential influence on present and future climate mitigation and adaptation activities in Jordan, especially in the educational and agricultural sectors.

\subsection{Sample Size}

The minimum sample size requirement of this study was 285 students. It was calculated using the following equation (Krejcie \& Morgan, 1970):

$$
n=\frac{\chi^{2 *} N * P(1-P)}{d^{2} *(N-1)+\chi^{2} * P(1-P)}
$$

where

$n$ : the due sample size

$\chi^{2}$ : the tabulated value of the Chi squared $\left(\chi^{2}\right)$ statistic for one degree of freedom $(d f)$ at the desired confidence level $(\alpha)$, which is 0.05 .

The number of degrees of freedom $(d f)$ is equal to the number of groups $(k)$ minus 1 (Eisenhauer, 2008; Turhan, 2020):

$d f=k-1$

In this study, the sample members are of two categories, or groups: 'Knowledgeable Students' and 'Non-knowledgeable Students'. Accordingly, the $k$ equals 2, and, thus, the $d f$ is 1 . Owing to that the desired confidence level $(\alpha)$ in the current study is 0.05 , the value of the $\chi^{2}$ statistic is 3.8416 , corresponding to $\chi=1.96$.

$N$ : population size (1096)

$P$ : population proportion $(0.50)$

This proportion is presumed to be 0.50 because it is the fraction that provides the maximal sample size (Krejcie \& Morgan, 1970). Indeed, it is quite a common practice to substitute $P$, which is unknown usually, with 0.5 because this is the value that maximizes $(P-1)$, i.e., the value that gives the most conservative (i.e., that is, the largest) sample size (Hajian-Tilaki 2011; Ramos et al. 2019).

$d$ : degree of accuracy (usually 5.0\% (0.05))

Since the numbers of students in the two study departments are unequal, then a proportional, or weighted, sample was randomly taken from each department as follows:

Number of sample physical science students $=\left(\frac{\text { Number of Physical Science Students }}{\text { Total Number of Students of the FAS }}\right) *$ Sample Size

Number of sample physical science students $=\left(\frac{396}{1096}\right) * 285 \cong 103$

Number of sample physical science students $=\left(\frac{700}{1096}\right) * 285 \cong 182$

The data collection process took about four weeks, extending from 10 June, 2021 to 10 July, 2021.

\subsection{Research Instrument}

This investigation used a knowledge test that was especially designed and developed by the researchers as the knowledge assessment and data collection tool for this study. This Climate Change Knowledge Test (CCKT) consisted of two main sections: (i) demographic information section and (ii) test section. The test section was made up of three sub-sections that define three sub-constructs (or sub-scales) of CC knowledge, namely, the (i) nature, (ii) causes, and (iii) effects of CC. Each of these sections consisted of 10 true-false questions (Table 1, Table 2, and 
Table 3). This CCKT was made available to the target respondents online via the 'Google Docs' tool (https://docs.google.com/forms/d/e/1FAIpQLSdDD7ycmMH5e1H5Pg3Rz6DQG59ltM_p20j8xprJltwfXZvXig/viewf orm).

Development of content valid instrument is ideally made by rational analysis of the instrument by experts in the research topic and/or experts who are familiar with the construct under consideration (Bolarinwa, 2015; DeVon et al., 2013). According to Boateng et al. (2018), content validity of the research tool is assessed mainly by a panel of experts. In view of this, the CCKT was subjected to content validation by three professors who are experts in assessment and evaluation and in climate change (CC) teaching and research. The three judges evaluated the instrument questions in terms of relevance, readability, accuracy, clarity, and interpretability (Table 1, Table 2, and Table 3).

In the light of the evaluation (Table 1, Table 2, and Table 3), the test statements were modified to good survey design. There was high agreement among the three expert judges on that the CCKT represents sufficient and representative measurement of knowledge of CC. Only few slight modifications to the first copy of the test were suggested (Table 1, Table 2, and Table 3). The test questions were, then, modified based on judges' evaluation.

Table 1. Climate Change Knowledge Test (CCKT): Nature of Climate Change

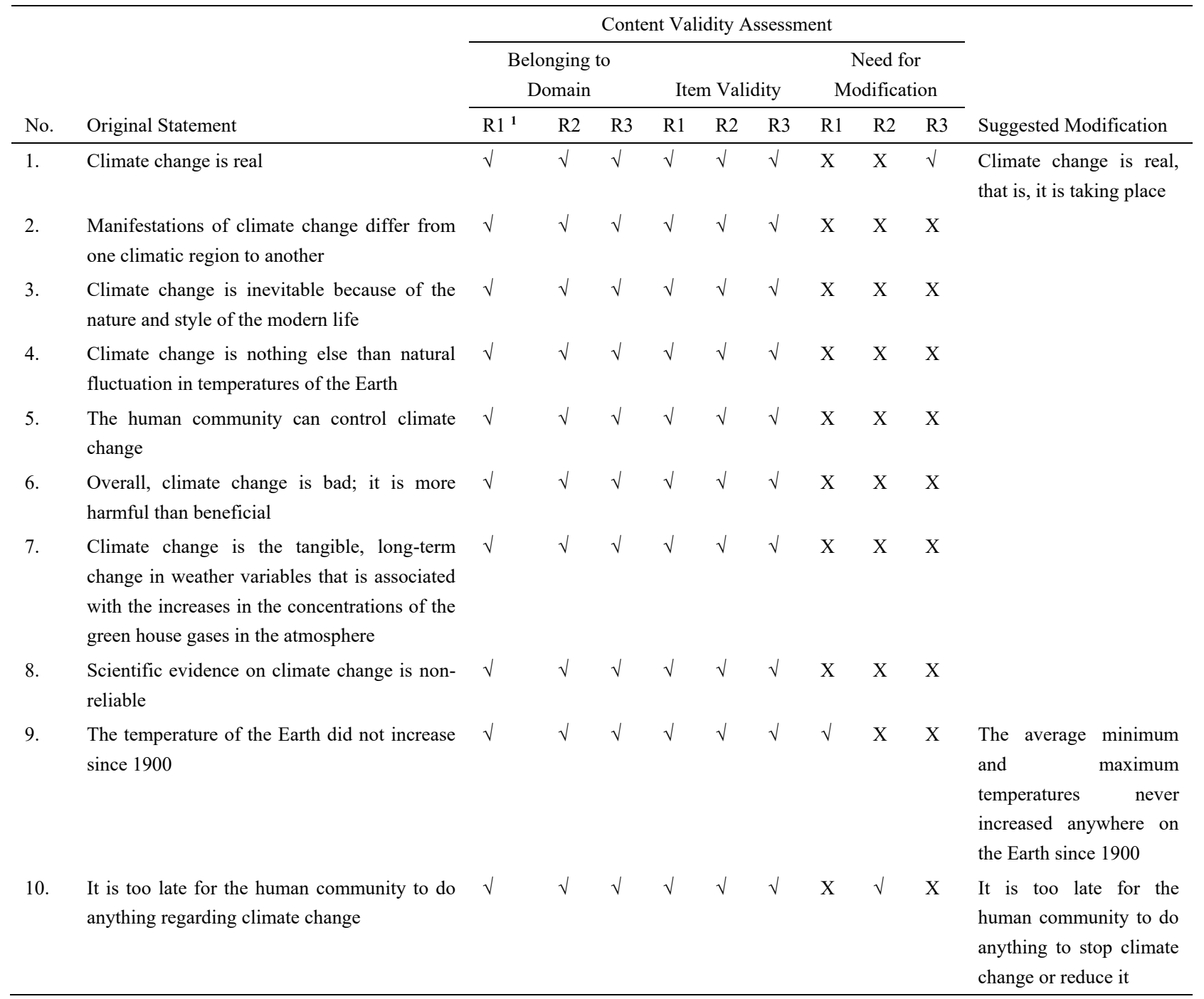

${ }^{1}$ R1: Referee 1. R2: Referee 2. R3: Referee 3. 
Table 2. Climate Change Knowledge Test (CCKT): Causes of Climate Change

\begin{tabular}{|c|c|c|c|c|c|c|c|c|c|c|c|}
\hline \multirow[b]{3}{*}{ No. } & \multirow[b]{3}{*}{ Original Statement } & \multicolumn{9}{|c|}{ Content Validity Assessment } & \multirow{3}{*}{$\begin{array}{l}\text { Suggested } \\
\text { Modification }\end{array}$} \\
\hline & & \multicolumn{3}{|c|}{$\begin{array}{l}\text { Belonging to } \\
\text { Domain }\end{array}$} & \multicolumn{3}{|c|}{ Item Validity } & \multicolumn{3}{|c|}{$\begin{array}{l}\text { Need for } \\
\text { Modification }\end{array}$} & \\
\hline & & $\mathrm{R} 1^{1}$ & $\mathrm{R} 2$ & R3 & $\mathrm{R} 1$ & $\mathrm{R} 2$ & R3 & $\mathrm{R} 1$ & $\mathrm{R} 2$ & R3 & \\
\hline 1. & $\begin{array}{l}\text { Environmental pollution resulting from industry is the } \\
\text { main cause of climate change }\end{array}$ & $\sqrt{ }$ & $\sqrt{ }$ & $\sqrt{ }$ & $\sqrt{ }$ & $\sqrt{ }$ & $\sqrt{ }$ & $\mathrm{X}$ & $\mathrm{X}$ & $\mathrm{X}$ & \\
\hline 2. & $\begin{array}{l}\text { Effect of human activities on temperatures of the } \\
\text { surface of the Earth is not high }\end{array}$ & $\sqrt{ }$ & $\sqrt{ }$ & $\sqrt{ }$ & $\sqrt{ }$ & $\sqrt{ }$ & $\sqrt{ }$ & $\mathrm{X}$ & $\mathrm{X}$ & $\mathrm{X}$ & \\
\hline 3. & $\begin{array}{l}\text { Burning of fossil fuel like oil and coal contributes to } \\
\text { climate change }\end{array}$ & $\sqrt{ }$ & $\sqrt{ }$ & $\sqrt{ }$ & $\sqrt{ }$ & $\sqrt{ }$ & $\sqrt{ }$ & $\mathrm{X}$ & $\mathrm{X}$ & $\mathrm{X}$ & \\
\hline 4. & Deforestation is one of the causes of climate change & $\sqrt{ }$ & $\sqrt{ }$ & $\sqrt{ }$ & $\sqrt{ }$ & $\sqrt{ }$ & $\sqrt{ }$ & $\mathrm{X}$ & $\mathrm{X}$ & $\mathrm{X}$ & \\
\hline 5. & $\begin{array}{l}\text { The cause of climate change is the global warming } \\
\text { associated with the increases in concentrations of the } \\
\text { green house gases in the atmosphere }\end{array}$ & $\sqrt{ }$ & $\sqrt{ }$ & $\sqrt{ }$ & $\sqrt{ }$ & $\sqrt{ }$ & $\sqrt{ }$ & $\mathrm{X}$ & $\mathrm{X}$ & $\mathrm{X}$ & \\
\hline 6. & $\begin{array}{l}\text { The transportation sector does not contribute } \\
\text { substantially to climate change }\end{array}$ & $\sqrt{ }$ & $\sqrt{ }$ & $\sqrt{ }$ & $\sqrt{ }$ & $\sqrt{ }$ & $\sqrt{ }$ & $\mathrm{X}$ & $\mathrm{X}$ & $\mathrm{X}$ & \\
\hline 7. & Climate change resulted mainly from the ozone hole & $\sqrt{ }$ & $\sqrt{ }$ & $\sqrt{ }$ & $\sqrt{ }$ & $\sqrt{ }$ & $\sqrt{ }$ & $\mathrm{X}$ & $\mathrm{X}$ & $\mathrm{X}$ & \\
\hline 8. & Climate change is a result of natural processes & $\sqrt{ }$ & $\sqrt{ }$ & $\sqrt{ }$ & $\sqrt{ }$ & $\sqrt{ }$ & $\sqrt{ }$ & $\mathrm{X}$ & $\sqrt{ }$ & $\mathrm{X}$ & $\begin{array}{l}\text { Climate change is } \\
\text { a result of natural } \\
\text { processes like } \\
\text { volcanoes rather } \\
\text { than human } \\
\text { activities }\end{array}$ \\
\hline 9. & $\begin{array}{l}\text { Agricultural activities such as animal and plant } \\
\text { production contribute to climate change }\end{array}$ & $\sqrt{ }$ & $\sqrt{ }$ & $\sqrt{ }$ & $\sqrt{ }$ & $\sqrt{ }$ & $\sqrt{ }$ & $X$ & $X$ & $X$ & \\
\hline 10. & $\begin{array}{l}\text { The sector with the highest contribution to climate } \\
\text { change is the energy sector }\end{array}$ & $\sqrt{ }$ & $\sqrt{ }$ & $\sqrt{ }$ & $\sqrt{ }$ & $\sqrt{ }$ & $\sqrt{ }$ & $X$ & $X$ & $X$ & \\
\hline
\end{tabular}

\footnotetext{
${ }^{1}$ R1: Referee 1. R2: Referee 2. R3: Referee 3.
} 
Table 3. Climate Change Knowledge Test (CCKT): Effects of Climate Change

\begin{tabular}{|c|c|c|c|c|c|c|c|c|c|c|c|}
\hline \multirow[b]{3}{*}{ No. } & \multirow[b]{3}{*}{ Original Statement } & \multicolumn{9}{|c|}{ Content Validity Assessment } & \multirow[b]{3}{*}{ Suggested Modification } \\
\hline & & \multicolumn{3}{|c|}{ Belonging to Domain } & \multicolumn{3}{|c|}{ Item Validity } & \multicolumn{3}{|c|}{ Need for Modification } & \\
\hline & & $\mathrm{R} 1^{1}$ & $\mathrm{R} 2$ & R3 & $\mathrm{R} 1$ & $\mathrm{R} 2$ & R3 & $\mathrm{R} 1$ & $\mathrm{R} 2$ & R3 & \\
\hline 1. & $\begin{array}{l}\text { Climate change causes } \\
\text { biodiversity loss }\end{array}$ & $\sqrt{ }$ & $\sqrt{ }$ & $\sqrt{ }$ & $\sqrt{ }$ & $\sqrt{ }$ & $\sqrt{ }$ & $\mathrm{X}$ & $X$ & $X$ & \\
\hline 2. & $\begin{array}{l}\text { Climate change brings } \\
\text { about drop in temperatures } \\
\text { of the Earth all over the } \\
\text { World }\end{array}$ & $\sqrt{ }$ & $\sqrt{ }$ & $\sqrt{ }$ & $\sqrt{ }$ & $\sqrt{ }$ & $\sqrt{ }$ & $\mathrm{X}$ & $\mathrm{X}$ & $\mathrm{X}$ & \\
\hline 3. & $\begin{array}{l}\text { Climate change leads to } \\
\text { soil fertility increase }\end{array}$ & $\sqrt{ }$ & $\sqrt{ }$ & $\sqrt{ }$ & $\sqrt{ }$ & $\sqrt{ }$ & $\sqrt{ }$ & $\mathrm{X}$ & $\mathrm{X}$ & $\mathrm{X}$ & \\
\hline 4. & $\begin{array}{l}\text { The human community } \\
\text { lives the effects of climate } \\
\text { change }\end{array}$ & $\sqrt{ }$ & $\sqrt{ }$ & $\sqrt{ }$ & $\sqrt{ }$ & $\sqrt{ }$ & $\sqrt{ }$ & $\mathrm{X}$ & $\mathrm{X}$ & $\sqrt{ }$ & $\begin{array}{l}\text { The human community } \\
\text { currently experiences the } \\
\text { effects of climate change } \\
\text { and suffers from them }\end{array}$ \\
\hline 5. & $\begin{array}{l}\text { Rise in water level in seas } \\
\text { is a result of climate } \\
\text { change }\end{array}$ & $\sqrt{ }$ & $\sqrt{ }$ & $\sqrt{ }$ & $\sqrt{ }$ & $\sqrt{ }$ & $\sqrt{ }$ & $\mathrm{X}$ & $\sqrt{ }$ & $\mathrm{X}$ & $\begin{array}{l}\text { Rise in water level in } \\
\text { seas and oceans and } \\
\text { submergence of islands } \\
\text { and adjacent lands are } \\
\text { results of climate change }\end{array}$ \\
\hline 6. & $\begin{array}{l}\text { Climate change leads to } \\
\text { decrease in incidence of } \\
\text { contagious and infectious } \\
\text { plant, animal, and human } \\
\text { diseases }\end{array}$ & $\sqrt{ }$ & $\sqrt{ }$ & $\sqrt{ }$ & $\sqrt{ }$ & $\sqrt{ }$ & $\sqrt{ }$ & $X$ & $X$ & $X$ & \\
\hline 7. & $\begin{array}{l}\text { Decline in plant and animal } \\
\text { food production, and, } \\
\text { hence, deterioration of food } \\
\text { security, may result from } \\
\text { climate change }\end{array}$ & $\sqrt{ }$ & $\sqrt{ }$ & $\sqrt{ }$ & $\sqrt{ }$ & $\sqrt{ }$ & $\sqrt{ }$ & $X$ & $X$ & $X$ & \\
\hline 8. & $\begin{array}{l}\text { Shortage of water that is } \\
\text { suitable for domestic use } \\
\text { and for irrigation of plants } \\
\text { and animals may result } \\
\text { from climate change }\end{array}$ & $\sqrt{ }$ & $\sqrt{ }$ & $\sqrt{ }$ & $\sqrt{ }$ & $\sqrt{ }$ & $\sqrt{ }$ & $X$ & $X$ & $X$ & \\
\hline 9. & $\begin{array}{l}\text { Climate change may cause } \\
\text { an increase in the } \\
\text { frequency and intensity of } \\
\text { extreme weather conditions } \\
\text { such as heat waves, } \\
\text { drought, hurricanes, and } \\
\text { heavy rains }\end{array}$ & $\sqrt{ }$ & $\sqrt{ }$ & $\sqrt{ }$ & $\sqrt{ }$ & $\sqrt{ }$ & $\sqrt{ }$ & $X$ & $X$ & $\sqrt{ }$ & $\begin{array}{l}\text { Climate change may } \\
\text { cause an increase in the } \\
\text { frequency and intensity } \\
\text { of extreme weather } \\
\text { conditions such as heat } \\
\text { waves, drought, } \\
\text { hurricanes, and heavy } \\
\text { rains in some areas in the } \\
\text { world }\end{array}$ \\
\hline 10. & $\begin{array}{l}\text { Climate change contributes } \\
\text { to increased wind and } \\
\text { water erosion of soil }\end{array}$ & $\sqrt{ }$ & $\sqrt{ }$ & $\sqrt{ }$ & $\sqrt{ }$ & $\sqrt{ }$ & $\sqrt{ }$ & $X$ & $X$ & $X$ & \\
\hline
\end{tabular}

${ }^{1}$ R1: Referee 1. R2: Referee 2. R3: Referee 3. 


\subsection{Statistical Analysis and Testing}

The research data were processed statistically using the Statistical Package for Social Sciences (SPSS, v24.0). The demographic data of the sample members were subjected to Frequency Distribution Analysis (FDA) in order to obtain a description of the study sample. Frequency Distribution Analysis was also applied to the individual statements of each sub-scale of the CCKT so as to determine the respondents' levels of knowledge of each studied facet of CC individually (the nature, causes, and effects of CC). Thereafter, descriptive statistics were calculated; the average counts and percentages of respondents were calculated for each of the three sub-scales individually so as to assess the respondents' overall level of knowledge of each of the three investigated aspects of CC.

In addition to this, the researchers conducted Shpiro-Wilk's Normality Test in order to determine whether or not the research data follow the Normal distribution. As well, the researchers performed group mean comparisons two times, once for the two gender groups, and once for the two 'Department' groups. Since in both cases the number of groups to compare was two, then the most appropriate test was the Two Independent-Sample $t$ Test. However, the ShapiroWilk's Normality Test uncovered that the research data (general knowledge of CC, knowledge of causes of CC, knowledge of effects of $\mathrm{CC}$, and overall knowledge of $\mathrm{CC}$ ) do not follow the Normal distribution. Thereupon, the Two Independent-Sample $t$ Test was replaced with its non-parametric equivalent, namely, the Mann-Whitney $U$ Test. In both comparisons, this test was conducted at the 0.05 level of significance $(\alpha)$.

\subsection{Categorization of Knowledge into Classes}

Knowledge of CC was categorized into three classes of knowledge; low, medium, and high, according to the formula for width of class interval ( $\left.w_{\mathrm{i}}\right)$ presented in Manikandan (2011) and Paternoster and Bachman (2018):

$$
w_{i}=\frac{\text { Range }}{\text { Number of Intervals }}
$$

where $w_{\mathrm{i}}$ is class interval width and range is the difference between the highest score and the lowest one:

$$
w_{i}=\frac{\text { Highest Score on the Scale }- \text { Lowest Score on the Scale }}{\text { Number of Classes }}
$$

Since the research tool is a knowledge test, then the highest score in the test is $100 \%$, corresponding to right answers to all test items. In the meantime, the lowest score is $0.0 \%$, corresponding to wrong answers to all test items. In consequence,

$$
w_{\mathrm{i}}=\frac{100 \%-0.0 \%}{3} \cong 33.3 \%
$$

Consequently, the three levels of knowledge are defined in terms of percentages of knowledgeable students as follows: low level of knowledge corresponds to percentage of knowledgeable students that is less than $33.3 \%$; medium level of knowledge is defined by percentage of knowledgeable students that falls in the range of $33.3 \%-66.6 \%$; and high level of knowledge is characterized by a percentage of knowledgeable students that is higher than $66.6 \%$.

\section{Results and Discussion}

\subsection{Demographic Characteristics of the Sample Students}

Outcomes of FDA (Table 4) reveal that the 285 sample members comprised 103 physical science students and 182 agricultural science students, corresponding to the percentages of $36.1 \%$ and $63.9 \%$, respectively. Female students constituted 85 members of the sample while the male students were 199 students. One record was missing the gender value, mostly because the respondent forgot to specify her/his gender.

As regards academic level, the numbers of first-year and second-year students in the sample were very close, 40 and 36, respectively (Table 4). Meantime, the numbers of third-year and fourth-year respondents were 89 and 120, respectively, which shows that the majority of the sample members were fourth-year students.

In terms of age, the study sample was dominated by students ranging in age from 21 to 25 years (Table 4). The number of these students was 125 students (i.e., $43.9 \%$ of the respondents). The age group of the second highest representation in the study sample was that of students ranging in age from 31 to 36 years. Their number was 46 
students, corresponding to $16.1 \%$ of the sample (Table 4). Thus, it is concluded that the study sample was dominated by male, fourth-year students, ranging in age from 21 to 25 years.

Table 4. Demographic Characteristics of the Sample Students $(N=285)$

\begin{tabular}{llll}
\hline Characteristic & Categories & Frequency & Valid \% \\
\hline Gender & Male & 199 & 70.1 \\
& Female & 85 & 29.9 \\
Age Group & $\leq 20$ Years & 22 & 7.7 \\
& 21-25 Years & 125 & 43.9 \\
& 26-30 Years & 46 & 16.1 \\
& 31-35 Years & 29 & 10.2 \\
& 36-40 Years & 27 & 9.5 \\
Department & > 40 Years & 36 & 12.6 \\
& Physical Sciences & 103 & 36.1 \\
Academic Level & Agricultural Sciences & 182 & 63.9 \\
& First Year & 40 & 14.0 \\
& Second Year & 36 & 12.6 \\
& Third Year & 89 & 31.2 \\
& Fourth Year & 120 & 42.1 \\
\hline
\end{tabular}

\subsection{Students' Knowledge of Climate Change}

Nature of CC was one of three aspects of general CC knowledge that were examined in this study. Outcomes of FDA (Table 5) uncover that more than $80.0 \%$ of the sample undergraduate students were knowledgeable of four issues: (i) definition of CC (84.2\% (Statement 7 in Table 5)); (ii) that climate change is real (86.7\% (Statement 1); (iii) that the manifestations of CC differ from climatic region to another $(84.6 \%$ (Statement 2$)$ ); and (iv) that the average temperatures increased in parts of the World since 1900 (80.7\% (Statement 9)). This leads the researchers to conclude that the majority of the sample members possess basic knowledge and understanding of CC. Percentages of respondents who know about the other investigated aspects of the nature of CC ranged from $58.9 \%$ (It is too late for the human community to do anything to stop climate change or reduce it (Statement 10)) to 76.4\% (Climate change is inevitable (Statement 3)).

The proportions of students providing right answers to Statement 10 and Statement 4 (Table 5) agree in the sense that nearly two thirds of the sample members (63.5\% (Statement 4$)$ ) think that CC is nothing else than natural fluctuation in temperatures of the Earth. As such, a close percentage of the sample students (58.9\% (Statement 10$)$ ) think that it is too late for the human community to do anything to stop climate change or reduce it because they think that CC is driven by natural forces and processes. Students' responses to Statement 8 too agree with the responses to Statement 4 and Statement 10, where nearly two thirds $(67.4 \%)$ of the sample students think that scientific evidence on CC is non-reliable. In the light of this finding, the researchers attract attention to that the issues covered by Statement 4 , Statement 8, and Statement 10 (Table 5) should be paid more attention by the faculty members in the FAS who carry the responsibility of instructing $\mathrm{CC}$ and related courses.

With reference to the categorization of the levels of knowledge into three distinct classes (Section 2.5), and based on the foregoing results (Table 5), this study found that the levels of students' knowledge of the individual facets of nature of CC were high in the case of four studied issues (Statements 1, 2, 7, and 9 (Table 5)) and moderate in the case of the rest six issues (Table 5). Overall, the results indicate that, on the average, the students' level of knowledge of the nature of $\mathrm{CC}$ is high because the average number of the sample students who provided correct answers to the 10 test statements was 209 students, that is, $73.5 \%$ of the whole sample members (Table 5). As Section 2.5 shows, this percentage $(73.5 \%$ ) falls within the class of high knowledge (percentage of knowledgeable students $>66.6 \%$ ). However, despite this high level of knowledge, the CC curricula in the FAS should pay special attention to illustrating the difference between $\mathrm{CC}$ and climate variability (Statement 4 in Table 5), explaining the positive and negative facets of CC (Statement 6), and clarifying the positive role of the human community in controlling CC (Statement 10) through mitigation and adaptation activities and practices. 
Table 5. Undergraduate Students' Knowledge of the Nature of Climate Change ${ }^{\text {a }}$

\begin{tabular}{|c|c|c|c|c|c|c|}
\hline \multirow[b]{3}{*}{ No. } & \multirow[b]{3}{*}{ Statement } & \multirow[b]{3}{*}{ Answer } & \multicolumn{4}{|c|}{ Responses } \\
\hline & & & \multicolumn{2}{|c|}{ Correct answer } & \multicolumn{2}{|c|}{ Wrong answer } \\
\hline & & & Freq. & $\%$ & Freq. & $\%$ \\
\hline 1. & Climate change is real, that is, it is taking place & True & 247 & 86.7 & 38 & 13.3 \\
\hline 2. & $\begin{array}{l}\text { Manifestations of climate change differ from one } \\
\text { climatic region to another }\end{array}$ & True & 241 & 84.6 & 44 & 15.4 \\
\hline 3. & $\begin{array}{l}\text { Climate change is inevitable because of the nature and } \\
\text { style of the modern life }\end{array}$ & True & 217 & 76.4 & 67 & 23.6 \\
\hline 4. & $\begin{array}{l}\text { Climate change is nothing else than natural fluctuation } \\
\text { in temperatures of the Earth }\end{array}$ & False & 181 & 63.5 & 104 & 36.5 \\
\hline 5. & The human community can control climate change & True & 194 & 68.3 & 90 & 31.7 \\
\hline 6. & $\begin{array}{l}\text { Overall, climate change is bad; it is more harmful than } \\
\text { beneficial }\end{array}$ & True & 183 & 64.4 & 101 & 35.6 \\
\hline 7. & $\begin{array}{l}\text { Climate change is the tangible, long-term change in } \\
\text { weather variables that is associated with the increases } \\
\text { in the concentrations of the green house gases in the } \\
\text { atmosphere }\end{array}$ & True & 240 & 84.2 & 45 & 15.8 \\
\hline 8. & Scientific evidence on climate change is non-reliable & False & 192 & 67.4 & 93 & 32.6 \\
\hline 9. & $\begin{array}{l}\text { The average minimum and maximum temperatures } \\
\text { never increased anywhere on the Earth since } 1900\end{array}$ & False & 230 & 80.7 & 55 & 19.3 \\
\hline \multirow[t]{2}{*}{10.} & $\begin{array}{l}\text { It is too late for the human community to do anything } \\
\text { to stop climate change or reduce it }\end{array}$ & False & 168 & 58.9 & 117 & 41.1 \\
\hline & & Average & 209 & 73.5 & 75 & 26.5 \\
\hline
\end{tabular}

${ }^{\text {a }}$ Any difference in number of respondents from 285 is due to missing value(s)

Causes of $\mathrm{CC}$ were the second aspect of $\mathrm{CC}$ knowledge that was investigated in this study. Table 6 reveals that the average number of the sample students who provided correct answers to the 10 items related to causes of CC is 166 students. In terms of percentage, it is found that $66.9 \%$ of the students had knowledge of the issues raised in the 10 statements under investigation (Table 6). With reference to the categorization of the levels of knowledge into three distinct classes (Section 2.5), this study finds that, on the average, the students' level of knowledge of causes of CC is high. Students' knowledge of causes of CC was low in the case of two issues (Statements 1 and 7 (Table 6)) and high in the case of the remainder eight issues (Table 6). Two issues proved to be confusing to those students since they were known by the least number of the sample students. These issues are (i) the exact role of environmental pollution resulting from industry in CC (Statement 1 in Table 6), which was known to only 66 out of the 285 students (23.2\% of the sample members) and (ii) the position of the ozone hole in the CC mechanism and process (Statement 7 in Table 6), which was known to 75 students only (23.2\%). Accordingly, and based on categorization of the levels of knowledge into classes (Section 2.5), the students' level of knowledge of these two issues is low.

Four issues in particular were known by the largest number of the sample students. Specifically, two hundred and fifty three students $(88.8 \%$ of the sample members) knew that burning of fossil fuel contributes to CC (Statement 3 in Table 6), two hundred and forty five students $(86.0 \%)$ knew that the cause of CC is the global warming associated with the increases in concentrations of the GHGs in the atmosphere (Statement 5), two hundred and thirty three students $(82.0 \%)$ knew that deforestation is one of the causes of CC (Statement 4), and two hundred and twenty six students $(79.6 \%)$ knew that the sector with the highest contribution to CC is the energy sector (Statement 10).

It is attracting attention that approximately one fourth of the sample students did not know that effect of human activities on temperatures of the surface of the Earth is high $(25.7 \%$ (Statement 2 in Table 6)) and that the transportation sector contributes substantially to CC (26.8\% (Statement 6)). As well, slightly less than one third of 
the sample students did not know that agricultural activities contribute to CC (31.9\% (Statement 9)) and that CC is more of anthropogenic than natural (32.4\% (Statement 8)).

Table 6. Undergraduate Students' Knowledge of Causes of Climate Change a

\begin{tabular}{|c|c|c|c|c|c|c|}
\hline \multirow[b]{3}{*}{ No. } & \multirow[b]{3}{*}{ Statement } & \multirow[b]{3}{*}{ Answer } & \multicolumn{4}{|c|}{ Responses } \\
\hline & & & \multicolumn{2}{|c|}{ Correct answer } & \multicolumn{2}{|c|}{ Wrong answer } \\
\hline & & & Freq. & $\%$ & Freq. & $\%$ \\
\hline 1. & $\begin{array}{l}\text { Environmental pollution resulting from industry is the } \\
\text { main cause of climate change }\end{array}$ & False & 66 & 23.2 & 219 & 76.8 \\
\hline 2. & $\begin{array}{l}\text { Effect of human activities on temperatures of the } \\
\text { surface of the Earth is not high }\end{array}$ & False & 211 & 74.3 & 73 & 25.7 \\
\hline 3. & $\begin{array}{l}\text { Burning of fossil fuel like oil and coal contributes to } \\
\text { climate change }\end{array}$ & True & 253 & 88.8 & 32 & 11.2 \\
\hline 4. & Deforestation is one of the causes of climate change & True & 233 & 82.0 & 51 & 18.0 \\
\hline 5. & $\begin{array}{l}\text { The cause of climate change is the global warming } \\
\text { associated with the increases in concentrations of the } \\
\text { green house gases in the atmosphere }\end{array}$ & True & 245 & 86.0 & 40 & 14.0 \\
\hline 6. & $\begin{array}{l}\text { The transportation sector does not contribute } \\
\text { substantially to climate change }\end{array}$ & False & 208 & 73.2 & 76 & 26.8 \\
\hline 7. & Climate change resulted mainly from the ozone hole & False & 75 & 26.3 & 210 & 73.7 \\
\hline 8. & $\begin{array}{l}\text { Climate change is a result of natural processes like } \\
\text { volcanoes rather than human activities }\end{array}$ & False & 192 & 67.6 & 92 & 32.4 \\
\hline 9. & $\begin{array}{l}\text { Agricultural activities such as animal and plant } \\
\text { production contribute to climate change }\end{array}$ & True & 194 & 68.1 & 91 & 31.9 \\
\hline \multirow[t]{2}{*}{10.} & $\begin{array}{l}\text { The sector with the highest contribution to climate } \\
\text { change is the energy sector }\end{array}$ & True & 226 & 79.6 & 58 & 20.4 \\
\hline & & Average & 190 & 66.9 & 94 & 33.1 \\
\hline
\end{tabular}

${ }^{a}$ Any difference in number of respondents from 285 is due to missing value(s)

Effects of $\mathrm{CC}$ were the third facet of $\mathrm{CC}$ knowledge that was examined in this study. With reference to categorization of the levels of knowledge into three classes (Section 2.5), the results of FDA (Table 7) point out that the level of sample students' knowledge of effects of CC was in general high (> 66.7\% knowledgeable students), except for a single case, which relates to the association of contagious and infectious plant, animal, and human diseases with CC (Statement 6 (Table 7)), where the sample students who know this association were 174 students only, corresponding to $61.1 \%$ of the study sample (Statement 6 in Table 7). A possibility holds that this issue is not covered, or, perhaps, not covered well, in the CC curricula in the FAS. On the other hand, three issues were known well by the majority of the sample students (Table 7)): association of extreme weather conditions with CC (89.1\% (Statement 9 in Table 7), that the human community experiences the effects of CC $(88.0 \%$ (Statement 4$)$, and that sea level rise is a consequence of CC (88.0\% (Statement 5$)$.

It is noticed that a higher proportion of the sample students were knowledgeable about the effects of CC $(79.3 \%$ knowledgeable students (Table 7)) than about its nature (73.9\% (Table 5)) and causes $(66.9 \%$ (Table 6)). In the light of the results presented in this sub-section, the CC curricula in the FAS need to be reviewed and modified in such a way as to fill the herein identified gaps in students' knowledge about CC, with particular emphasis on CC causes, mechanism, and processes. The students of both departments of the FAS in Jarash University can gain further, improved knowledge of $\mathrm{CC}$ from upgraded, more comprehensive curricula on $\mathrm{CC}$ than the current ones.

Comparable findings have been reported by previous studies of CC knowledge. For instance, Yang et al. (2018) investigated association between knowledge of the causes of CC and its perceived impacts. They performed countrywide cross-sectional survey and collected data from 1387 nursing, public health, and medical students enrolled in five regional universities in China. They found that nearly $83.0 \%$ of their sample students believed that $\mathrm{CC}$ is generally bad, which is a percentage that is higher than that obtained in the present study; $64.4 \%$ (Table 5). In 
addition, almost $67.0 \%$ of the respondents in their study believed that CC is controllable. A very close percentage was obtained in the current study $(68.3 \%$ (Table 5$))$. Moreover, nearly $58 \%$ of the respondents in their study could successfully identify the causes of CC. On this account, Yang et al. (2018) concluded that knowledge about the causes of CC is poor amongst the students in China. The sample students in the present study demonstrated almost moderate knowledge of causes of CC. However, a higher percentage of the respondents in the current study (66.9\% (Table 6)) could correctly identify the causes of CC. Furthermore, most of the respondents in the study of Yang et al. (2018) agreed on the rising Earth temperatures (64\%) and contribution of the human activities to CC (77\%). The corresponding percentages in the present study are $80.7 \%$ and $74.3 \%$, respectively.

Table 7. Undergraduate Students' Knowledge of Effects of Climate Change a

\begin{tabular}{|c|c|c|c|c|c|c|}
\hline \multirow[b]{3}{*}{ No. } & \multirow[b]{3}{*}{ Statement } & \multirow[b]{3}{*}{ Answer } & \multicolumn{4}{|c|}{ Responses } \\
\hline & & & \multicolumn{2}{|c|}{ Correct answer } & \multicolumn{2}{|c|}{ Wrong answer } \\
\hline & & & Freq. & $\%$ & Freq. & $\%$ \\
\hline 1. & Climate change causes biodiversity loss & True & 238 & 83.8 & 46 & 16.2 \\
\hline 2. & $\begin{array}{l}\text { Climate change brings about drop in temperatures of } \\
\text { the Earth all over the World }\end{array}$ & False & 195 & 68.4 & 90 & 31.6 \\
\hline 3. & Climate change leads to soil fertility increase & False & 192 & 67.6 & 92 & 32.4 \\
\hline 4. & $\begin{array}{l}\text { The human community currently experiences the } \\
\text { effects of climate change and suffers from them }\end{array}$ & True & 250 & 88.0 & 34 & 12.0 \\
\hline 5. & $\begin{array}{l}\text { Rise in water level in seas and oceans and } \\
\text { submergence of islands and adjacent lands are results } \\
\text { of climate change }\end{array}$ & True & 228 & 88.0 & 57 & 12.0 \\
\hline 6. & $\begin{array}{l}\text { Climate change leads to decrease in incidence of } \\
\text { contagious and infectious plant, animal, and human } \\
\text { diseases }\end{array}$ & False & 174 & 61.1 & 111 & 38.9 \\
\hline 7. & $\begin{array}{l}\text { Decline in plant and animal food production, and, } \\
\text { hence, deterioration of food security, may result from } \\
\text { climate change }\end{array}$ & True & 232 & 81.4 & 53 & 18.6 \\
\hline 8. & $\begin{array}{l}\text { Shortage of water that is suitable for domestic use and } \\
\text { for irrigation of plants and animals may result from } \\
\text { climate change }\end{array}$ & True & 242 & 84.9 & 43 & 15.1 \\
\hline 9. & $\begin{array}{l}\text { Climate change may cause an increase in the frequency } \\
\text { and intensity of extreme weather conditions such as } \\
\text { heat waves, drought, hurricanes, and heavy rains in } \\
\text { some areas in the world }\end{array}$ & True & 253 & 89.1 & 31 & 10.9 \\
\hline \multirow[t]{2}{*}{10.} & $\begin{array}{l}\text { Climate change contributes to increased wind and } \\
\text { water erosion of soil }\end{array}$ & True & 230 & 80.7 & 55 & 19.3 \\
\hline & & Average & 223 & 79.3 & 61 & 20.7 \\
\hline
\end{tabular}

${ }^{\text {a }}$ Any difference in number of respondents from 285 is due to missing value(s)

Likewise, the results of the present study coincide much with those of the study of La Torre et al. (2020), though the sample students of the present study in general demonstrated somewhat higher level of CC knowledge. The issues with which a high degree of agreement is noticed between these two studies are the following: climate change causes steady rise in the temperature of the Earth (79.3\% (La Torre et al. (2020)); 80.7\% (the present study)); climate change leads to rise in sea level $(80.7 \% ; 88.0 \%)$; climate change results in biodiversity loss $(78.4 \% ; 83.8 \%)$; climate change impacts food production negatively $(80.1 \% ; 81.4 \%)$; climate change contributes to water shortage $(79.8 \%$; $84.9 \%)$; extreme weather conditions will be associated with CC (77.5\%; 89.1\%); and climate change contributes to spread of diseases $(79.7 \% ; 61.1 \%)$. It is worth mentioning that the number of Italian university students in the sample of the study of La Torre et al. (2020) is equal to the number of students in the current study ( 285 students). However, the research tool which La Torre et al. (2020) used in their study paid more attention to effects of CC than to balanced coverage of the nature, causes, and effects of CC as in the present study. 
There are cases of very high levels of knowledge of CC. For instance, a higher percentage $(89.2 \%)$ of the sample university students in the study of Ojomo et al. (2015) realized that human activities are responsible for CC than the percentage of the sample university students in the present study (74.3\% (Table 3)). Another example of studies reporting very high levels of CC knowledge is the study of Agboola and Emmanuel (2016), which assessed awareness of CC and sustainable development amongst 300 undergraduate students in two universities in Nigeria: Ladoke Akintola University of Technology and University of Ibadan. They found that $97.0 \%$ of the sample students realized that CC is happening and that $94.3 \%$ of the students knew that it manifests differently in different regions in the World while $92.1 \%$ agreed on that the human community experiences the CC effects. Meantime, about $87.2 \%$ of the students knew that CC is more harmful than beneficial, nearly $78.2 \%$ realized that it is caused mostly by human activities, almost $85.5 \%$ knew that it increases temperature of the surface of the Earth, nearly $80.6 \%$ realized that it leads to rise in sea level, and $88.2 \%$ agreed on that it increases the intensity of extreme weather conditions. The corresponding percentages in the current study are $86.7 \%$ (Table 5), $84.6 \%$ (Table 5), 88.0\% (Table 7), 64.4\% (Table 5), $67.6 \%$ (Table 6), $68.4 \%$ (Table 7), $88.0 \%$ (Table 7), and $89.1 \%$ (Table 7), respectively. However, while the CCKT designed and developed in the present study is characterized by balanced coverage and representation of the nature, causes, and effects of $\mathrm{CC}$, the instrument (questionnaire) employed in the study of Agboola and Emmanuel (2016) lacks balance as it concentrates on effects, then nature, of CC, with extremely limited coverage of its causes.

The level of knowledge reported in this study and that of Yang et al. (2018) are, nonetheless, very much better than levels reported by other previous studies. For example, in a study of the level of awareness of CC among tertiary education students in Nigeria, Oruonye (2011) found that $72.8 \%$ of the 225 sample students did not know what CC is, what its causes and effects are, and what the mitigation and adaptation measures are. Only $32.9 \%$ of these students realized that $\mathrm{CC}$ is controllable. In the present study, the percentage of undergraduate students who realize that $\mathrm{CC}$ is controllable is slightly more than twice that percentage (68.3\% (Table 5)). Additionally, only $4.0 \%$ of the sample students in the study of Oruonye (2011) knew about association of extreme weather condition with CC. The corresponding percentage in the current study is $89.1 \%$ (Table 6).

Another example of studies reporting low levels of CC knowledge is the study of Jamelske et al. (2015). These researchers examined differences in opinion on CC between college students in the USA and China. The study addressed personal beliefs, understanding of science, concerns, and perceptions of threat. The study sample consisted of 2335 American and 1670 Chinese university students. In general, the American students manifested a lower level of understanding of science than the Chinese students. Specifically, the percentages of students agreeing on that global warming and CC are happening were $52.8 \%$ and $73.9 \%$ of the American and Chinese students, respectively. In addition, nearly $40.6 \%$ and $55.4 \%$ of the American and the Chinese students, respectively, agreed on that global warming and $\mathrm{CC}$ are primarily caused by human activities. The corresponding percentages in the current study are $86.7 \%$ (Table 5) and $67.7 \%$ (Table 6), respectively. This suggests that the sample FAS students possess higher levels of CC knowledge than the students who participated in the study of Jamelske et al. (2015).

A low level of CC knowledge has also been reported by Barreda (2018), who explored level of CC awareness of undergraduate students in Partido State University in the Philippines. Specifically, only 15.64\% of their 247 sample students knew that CC is happening, about $15.38 \%$ of the sample students realized that $\mathrm{CC}$ manifests in various ways in the World, and $15.41 \%$ of the students knew that the human community already experiences the impacts of CC. For comparison purposes, the concomitant percentages in the present study are $86.7 \%$ (Table 7), 84.6\% (Table 5), and $88.0 \%$ (Table 7 ).

While the comparisons presented in the foregoing three paragraphs are informative, they should be interpreted with caution because most of the previous investigations of CC knowledge, awareness, and perception used questionnaires rather than tests as the knowledge assessment tool, which is not much of a sound practice since the questionnaire probes points of views on, or degrees of agreement with, the instrument items. Only a very small number of the studies cited in this paper used test as the knowledge assessment tool (e.g., Baer et al., 2019; Falaye \& Okwilagwe, 2016; Parant, Pascual, \& Jugel, 2016; Sundblad, Biel, \& Gärling, 2009; Yang et al., 2018).

To conclude, the differences between the results of this study and those of similar previous studies are justifiable, bearing in mind that these studies differed in many respects, including study population, sample size and composition, research instrument, population culture, and educational contexts. Furthermore, in previous studies of CC knowledge targeting university students, the samples included undergraduate students from many disciplines, rather than only science and agriculture students. 


\subsection{Differences between the Sample Students in Knowledge of Climate Change}

This study took into consideration the possibility of statistically-significant differences between the male and female students, as well as between the DPS and DAS students, in knowledge about CC. To this end, comparisons were made. However, the Shapiro-Wilk's Normality Test disclosed that none of the study variables (knowledge of nature of CC, knowledge of causes of CC, knowledge of effects of CC, and overall knowledge of CC) follows the normal distribution. Thereupon, the comparisons between groups were made using the Mann-Whitney $U$ Test, which is the non-parametric equivalent of the Two-Independent Sample $t$-Test. All tests were conducted at $\alpha$ of 0.05 .

Gender differences were detected. Outputs of the Mann-Whitney $U$ Test (Table 8 ) uncover that there are statisticallysignificant differences between the sample male and female students in knowledge of the nature of CC $(U=6723.0$, Asymp. Sig. $(p)=0.006)$; knowledge of the causes of CC $(U=7049.5, p=0.023)$; knowledge of effects of CC $(U=$ $6440.5, p=0.001)$; and the overall knowledge of CC $(U=6452.0, p=0.002)$.

Table 8. Comparison between Male and Female Students in Climate Change Knowledge

\begin{tabular}{|c|c|c|c|c|c|}
\hline \multicolumn{6}{|c|}{ Test statistics ${ }^{\mathbf{a}}$} \\
\hline \multirow{2}{*}{\multicolumn{2}{|c|}{ Test statistic }} & \multicolumn{4}{|c|}{ Knowledge about CC } \\
\hline & & Nature & Causes & Effects & Overall knowledge \\
\hline Mann-Whitney $U$ & & 6723.000 & 7049.500 & 6440.500 & 6452.000 \\
\hline Wilcoxon $W$ & & 26623.000 & 26949.500 & 26340.500 & 26352.000 \\
\hline$Z$ & & -2.775 & -2.273 & -3.237 & -3.174 \\
\hline Asymp. Sig. (2-tailed) & & .006 & .023 & .001 & .002 \\
\hline \multicolumn{6}{|c|}{${ }^{\mathrm{a}}$ Grouping variable: Gender. Level of statistical significance $(\alpha): 0.05$. } \\
\hline \multicolumn{6}{|c|}{ Ranks } \\
\hline \multirow{2}{*}{\multicolumn{2}{|c|}{ Group }} & \multicolumn{4}{|c|}{ Mean rank } \\
\hline & & Nature & Causes & Effects & Overall knowledge \\
\hline \multirow{2}{*}{\multicolumn{2}{|c|}{$\begin{array}{l}\text { Male students }(n=199) \\
\text { Female students }(n=85)\end{array}$}} & 133.78 & 135.42 & 132.36 & 132.42 \\
\hline & & 162.91 & 159.06 & 166.23 & 166.09 \\
\hline \multicolumn{6}{|c|}{ Descriptive statistics } \\
\hline Group & Statistic & Nature & Causes & Effects & Overall knowledge \\
\hline \multirow[t]{2}{*}{ Male students $(n=199)$} & Mean & 7.15 & 6.55 & 7.62 & 21.32 \\
\hline & Median & 7.00 & 7.00 & 8.00 & 22.00 \\
\hline \multirow[t]{2}{*}{ Female students $(n=85)$} & Mean & 7.78 & 6.96 & 8.33 & 23.07 \\
\hline & Median & 8.00 & 7.00 & 9.00 & 24.00 \\
\hline
\end{tabular}

Taking into consideration that the sample female students have higher mean knowledge rank and mean and median scores on all four constructs (Table 8) than their male peers, it is concluded that the female students have higher knowledge of CC than their male peers. As an illustration, the sample female students have higher mean 'Overall CC Knowledge' rank (166.09) than the male students (132.42). They also have higher mean and median scores on the 'Overall CC Knowledge' scale (23.07 and 24.00, respectively) than their male peers (21.32 and 22.00, respectively).

This finding of female advantage in knowledge accords with findings of earlier studies which reported higher performance of female than male students. Workman and Heyder (2020) maintain that the female students often surpass their male peers in a number of academic performance indicators. Based on meta-analysis, Voyer and Voyer (2014) too found that female students quite often gain higher grades than their male peers. One of the explanations of the gender gap in academic performance and grades in favor of the female students is competence differences (Workman \& Heyder, 2020); female students have higher competence than male students (Voyer \& Voyer, 2014; Workman \& Heyder, 2020). In addition to that, and according to Voyer and Voyer (2014), the female advantage in academic achievement can be ascribed to several, mainly social, factors, including (i) differential attributions by parents, (ii) stereotype threat, and (iii) gender differences in the learning styles. The differential attributions made by the parents can make them encourage more efforts in the females than in the males. Difference in extent of encouragement may in part explain the general female advantage in marks. Influence of stereotype threat is noteworthy social factor that has been proposed as probable explanation of the gender difference in achievement. This sort of threat exists when performance of a group is influenced by the common impression that its members belong to social group who is not anticipated to perform well in specific task(s). In this regard, Hartley and Sutton 
(2013) reported that even at early age, both the boys and the girls hold a belief that the adults expect the girls to be better students than the boys. They showed that nullifying or stressing this belief had positive or negative impact, respectively, on the boys' performance in reading, writing, and mathematics, without influencing the girls' performance. Lastly, gender differences in the learning styles can explain the female advantage in academic performance. Kenney-Benson et al. (2006) clarified that the learning style of the female students is mastery-, rather than task-oriented. The male students, on the other hand, manifest the inverse emphasis. The emphasis on mastery means that the student performs the academic work in hope of achieving an understanding of the learning material while the emphasis on performance is characterized by a focus on the marks. In general, mastery emphasis leads to higher grades than the performance emphasis, which may, at least partially, explain why the female students frequently obtain higher grades than their male peers. In other respects, another potential explanation of the higher knowledge scores of the sample female students is their high reliance on academic success. In this context, Herrmann et al. (2019) demonstrated that the female students have higher risk of developing the symptoms of school burnout than the male students, which is explained by their feeling of self-worth as they depend more on academic success than the male students. Accordingly, the researchers maintain that the female advantage in CC knowledge reported in this paper is explained by competence differences, differential attributions by parents, stereotype threat, gender differences in the learning styles, and higher dependence of female than male students on academic success.

Department differences were found. Outcomes of the Mann-Whitney $U$ Test (Table 9) disclose that there are statistically-significant differences between the DPS and DAS students in knowledge of the nature of CC $(U=$ $7143.5, p=0.001)$; knowledge of the causes of CC $(U=7646.5, p=0.008)$; knowledge of effects of CC $(U=$ $6352.5, p=0.000)$; and the overall knowledge of CC $(U=6481.5, p=0.000)$.

Table 9. Comparison between the DPS and DAS Students in Climate Change Knowledge

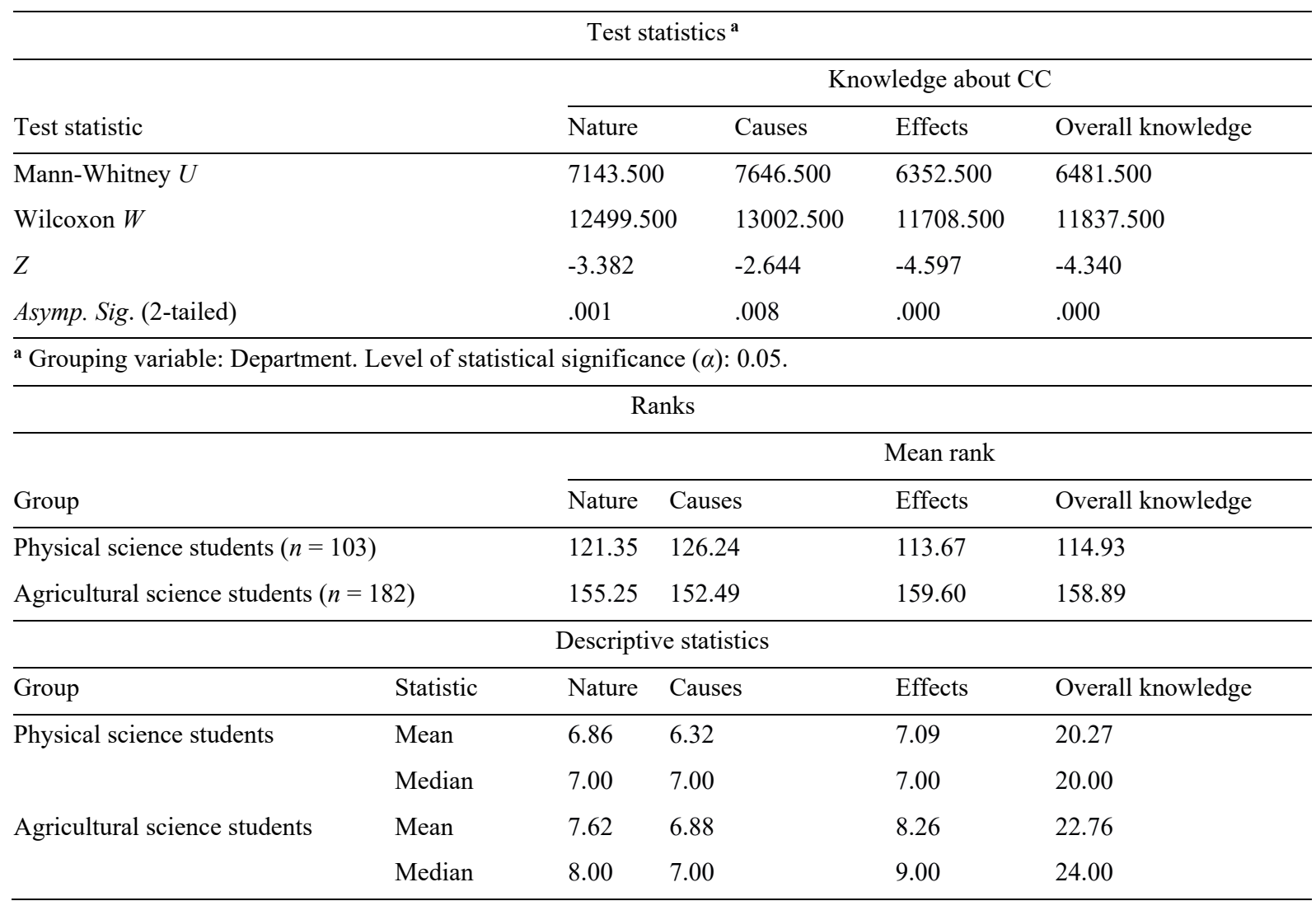

The finding that the DAS sample students have higher mean knowledge rank and mean and median scores on all four constructs (Table 9) than the DPS students leads to the conclusion that the DAS students have higher knowledge of $\mathrm{CC}$ than the DPS students. For example, the sample DAS students have higher mean 'Overall CC Knowledge' rank (158.89) than the DPS students (114.93). Moreover, they have higher mean and median scores on the 'Overall CC 
Knowledge' scale (22.76 and 24.00, respectively) than their DPS peers (20.27 and 20.00, respectively). This finding is explained by the fact that the majority of the DAS students usually join two elective courses with CC focus during their study for the B.Sc degree: Environmental Science and Agriculture and Climate Change and the Sustainability Policy. Quite often, only one of these two courses (Climate Change and the Sustainability Policy) is joined by DPS students. Further, the number of DPS students who usually join this course is commonly not high. Accordingly, the DAS students have higher exposure to CC knowledge during their course of study than the DPS students.

Rarely were comparisons in knowledge held between the demographic groups of the sample members in previous studies. For this reason, the results presented in this section could not be compared with findings of previous studies. One exception, however, is the study of Agboola and Emmanuel (2016), which reported lack of significant difference in the level of awareness of $\mathrm{CC}$ and sustainable development between the male and female students in their sample. However, these researchers did not provide an explanation of this finding.

\section{Conclusions}

Owing to that the undergraduate university students are the future leaders of their countries and since the young adults usually have longer life span and are, accordingly, more vulnerable than others to the long-term effects of CC, their knowledge of this topic is of substantial interest. This study contributes to the literature on undergraduate students' knowledge of the nature, causes, and effects of CC. The findings suggest that the physical science and agricultural science students in the FAS do, in general, possess high knowledge of the CC issues addressed by this study, but still need an improved education to effectively participate in future education and knowledge dissemination efforts and $\mathrm{CC}$ response (mitigation and adaptation) initiatives. Incorporating education on CC causes, mechanism, processes, and effects into university courses will help in raising awareness and increasing future generations' preparedness for the civic social responsibility. As Oruonye (2011) maintains, these university students can in their turn, if properly educated, lead others in CC awareness crusades.

Many lessons have been learnt from the results of this study. One is the need to focus in environmental science and $\mathrm{CC}$ courses on causes, mechanism, and processes of CC. Either these aspects of $\mathrm{CC}$ are not covered by the current curricula in the FAS or the students are not much able to understand the mechanism of CC as it involves somehow complicated processes and pathways. Another issue that merits further attention in the curricula is association of contagious and infectious plant, animal, and human diseases with CC. The second important learnt lesson is the need for the academic administration of the university to transfer the CC courses from the list of university-level elective courses to the list of faculty-level compulsory courses or department-level elective courses to ensure that the vast majority of the students of the FAS will enroll in these courses and benefit from the knowledge contained in them. Re-defining the environmental science and CC courses as faculty-level compulsory courses ensures that all undergraduate students of the FAS will enroll in these courses and gain reasonably satisfactory knowledge of global environmental challenges, in general, and CC, in particular, and brings the level of CC knowledge of the DPS students close to that of their DAS peers.

The approach to knowledge assessment using a test, rather than a questionnaire, that was adopted in this study and the test itself constitute benchmark approach and CC knowledge test (CCKT) that other researchers can employ to assess CC knowledge and identify gaps in it. As well, this approach and test can inform the design of evidence-based environmental science and CC curricula. The current curricula in the FAS seem to be covering nature and effects of $\mathrm{CC}$ well. However, the results of this study demonstrate the need for a focus in the $\mathrm{CC}$ and related courses on causes, mechanism, and processes of CC, as well as on the location of the ozone layer and depletion in the CC process. As the first known study performed in Jordan to assess knowledge of science and agriculture university students' knowledge of the nature, causes, and effects of $\mathrm{CC}$, the results inform decision makers and educational leaders of the need for curriculum reform. Furthermore, the results of this study may help the faculty members in further incorporation of $\mathrm{CC}$ aspects into their teaching deliveries.

\section{Acknowledgements}

The researchers deeply thank Prof. Ali J. Al-Sharafat (Jarash University, Jordan), Dr. Jamal Alrusheidat (Jarash University, Jordan), and Prof. Mahmoud M. Abu-Allaban (The Hashemite University) for their kind referring of the research tool. Their comments and suggestions were highly valuable contribution to validity of the research tool and to credibility of the study and reliability of its results. 


\section{References}

Agboola, O. S., \& Emmanuel, M. (2016). Awareness of climate change and sustainable development among undergraduates from two selected universities in Oyo State, Nigeria. World Journal of Education, 6(3), 70-81. https://doi.org/10.5430/wje.v6n3p70

Akrofi, M. M., Antwi, S. H., \& Gumbo, J. R. (2019). Students in climate action: A study of some influential factors and implications of knowledge gaps in Africa. Environments, $6(12)$, 1-15. https://doi.org/10.3390/environments6020012

Akter, S., \& Bennett, J. (2011). Household perceptions of climate change and preferences for mitigation action: The case of the Carbon Pollution Reduction Scheme in Australia. Climatic Change, 109, 417-436. https://doi.org/10.1007/s10584-011-0034-8

Baer, A. P., Sestili, C., Cocchiara, R. A., Barbato, D., Del Cimmuto A., \& La Torre, G. (2019). Perception of climate change: Validation of a questionnaire in Italy. Clinical Therapeutics, 170(3), e184-191. https://doi.org/10.7417/CT.2019.2131

Barimah, P. T., Kwadwo, S. O., \& David, O. (2015). Assessment of people's knowledge and perception on climate change: A case study of Asunafo North District, Ghana. International Journal of Innovative Science Engineering and Technology, 4(1), 18417-18424. https://doi.org/10.15680/IJIRSET.2015.0401003

Barkmann, T., Siebert, R., \& Lange, A. (2017). Land-use experts' perception of regional climate change: An empirical analysis from the North German Plain. Climatic Change, 144, $287-301$. https://doi.org/10.1007/s10584-017-2041-X

Barreda, A. B. (2018). Assessing the level of awareness on climate change and sustainable development among students of Partido State University, Camarines Sur, Philippines. Journal of Sustainability Education, 17, 1-17. https://doi.org/10.13140/rg.2.2.25047.29601

Boateng, G. O., Neilands, T. B., \& Frongillo, E. A. (2018). Best practices for developing and validating scales for health, social, and behavioral research: A primer. Frontiers in Public Health, 6(149), 1-18. https://doi.org/10.3389/fpubh.2018.00149

Bolarinwa, O. A. (2015). Principles and methods of validity and reliability testing of questionnaires used in social and health science researches. Nigerian Postgraduate Medical Journal, 22(4), 195-201. https://doi.org/10.4103/1117-1936.173959

Bord, R. J., O’Connor, R. E., \& Fisher, A. (2000). In what sense does the public need to understand global climate change? Public Understanding of Science, 9(3), 205-218. https://doi.org/10.1088/0963-6625/9/3/301

Christensen, R., \& Knezek, G. (2015). The Climate Change Attitude Survey: Measuring middle school student beliefs and intentions to enact positive environmental change. International Journal of Environmental \& Science Education, 10(5), 773-788. https://doi.org/10.12973/ijese.2015.276a

Crowley, T. J. (2000). Causes of climate change over the past 1000 years. Science, 289(5477), $270-277$. https://doi.org/10.1126/science.289.5477.270

Dal, B., Ozturk, N., \& Alper, U. (2014). Perception of climate change: Reasons, consequences, and willingness to act. How aware are they? International Journal for Cross-Disciplinary Subjects in Education (Special Issue), 4(2), 1930-1937. https://doi.org/10.20533/ijcdse.2042.6364.2014.0268

DeVon, H. A., Block, M. E., Moyle-Wright, P., Ernst, D. M., Hayden, S. J., Deborah J. ... Kostas-Polston, E. (2007). A psychometric toolbox for testing validity and reliability. Journal of Nursing Scholarship, 39(2), 155-64. https://doi.org/10.1111/j.1547-5069.2007.00161.x

Dhanya, P., \& Ramachandran, A. (2016). Farmers' perceptions of climate change and the proposed agriculture adaptation strategies in a semi arid region of south India. Journal of Integrative Environmental Science, 13(1), 1-18. https://doi.org/10.1080/1943815X.2015.1062031

Eisenhauer, J. G. (2008). Degrees of freedom. Teaching Statistics, 30(3), $75-78$. https://doi.org/10.1111/j.1467-9639.2008.00324.x

Etkin, D., \& Ho, E. (2009). Climate change: Perceptions and discourses of risk. Journal of Risk Research, 10(5), 623-641. https://doi.org/10.1080/13669870701281462

Falaye, F. V., \& Okwilagwe, E. A. (2016). Assessing the senior school students' knowledge, attitude and practices 
related to climate change: Implications for curriculum review and teacher preparation. Journal of the International Society for Teacher Education, 20(1), 43-53.

Frigg, R., Thompson, E., \& Wernd, C. (2015). Philosophy of climate science. Part I: Observing climate change. Philosophy Compass, 10(12), 953-964. https://doi.org/10.1111/phc3.12294

Haines, A., \& Ebi, K. (2019). The imperative for climate action to protect health. New England Journal of Medicine, 380(17), 263-273. https://doi.org/10.1056/NEJMra1807873

Hajian-Tilaki, K. (2011). Sample size estimation in epidemiologic studies. Caspian Journal of Internal Medicine, 2(4), 289-298.

Hartley, B. L., \& Sutton, R. M. (2013). A stereotype threat account of boys' academic underachievement. Child Development, 84, 1716-1733. https://doi.org/10.1111/cdev.12079

Herrmann, J., Koeppen, K., \& Kessels, U. (2019). Do girls take school too seriously? Investigating gender differences in school burnout from a self-worth perspective. Learning and Individual Differences, 69, 150-161. https://doi.org/10.1016/j.lindif.2018.11.011

Hulme, M., Dessai, S., Lorenzoni, I., \& Nelson, D.R. (2009). Unstable climates: Exploring the statistical and social constructions of climate. Geoforum, 40, 197-206. https://doi.org/10.1016/j.geoforum.2008.09.010

Jamelske, E., Boulter, J. Jang, W., Barrett, J., Miller, L., \& Han, W. L. (2015). Examining differences in public opinion on climate change between college students in China and the USA. Journal of Environmental Studies and Sciences, 5, 87-98. http://dx.doi.org/10.1007/s13412-015-0229-9

Jamshidi, O., Asadi, A., Kalantari, K., \& Azadi, H. (2018). Perception, knowledge, and behavior towards climate change: A survey among agricultural professionals in Hamadan Province, Iran. Journal of Agricultural Science and Technology, 20, 1369-1382. https://doi.org/10.1016/j.crm.2018.06.002

Jørgensen, S. L., \& Termansen, M. (2016). Linking climate change perceptions to adaptation and mitigation action. Climatic Change, 138(1), 283-296. https://doi.org/10.1007/s10584-016-1718-x

Kabir, M. I., Rahman, M. B., Smith, W., Lusha, M. A. F., Azim, S., \& Milton, A. H. (2016). Knowledge and perception about climate change and human health: Findings from a baseline survey among vulnerable communities in Bangladesh. BMC Public Health, 16(266), 1-10. https://doi.org/10.1186/s12889-016-2930-3

Kenney-Benson, G. A., Pomerantz, E. M., Ryan, A. M., \& Patrick, H. (2006). Sex differences in math performance: The role of children's approach to schoolwork. Developmental Psychology, 42, 11-26. https://doi.org/10.1037/0012-1649.42.1.11

Koutsoyiannis, D. (2021). Rethinking climate, climate change, and their relationship with water. Water, 13(849), 1-38. https://doi.org/10.3390/w13060849

Krejcie, R. V., \& Morgan, D. W. (1970). Determining sample size for research activities. Educational and Psychological Measurement, 30(3), 607-610. https://doi.org/10.1177/001316447003000308

La Torre, G., Baer, A. D. P., Sestili, C., Cocchiara, R. A., Barbato, D., Mannocci, A., \& Del Cimmuto, A. (2020). Knowledge and perception about climate change among healthcare professionals and students: A cross-sectional study. South Eastern European Journal of Public Health, XIII, 1-19. https://doi.org/10.4119/seejph-3347

Lineman, M., Do, Y., Kim, J. Y., \& Joo, G. (2015). Talking about climate change and global warming. PLoS ONE, 10(9), e0138996. https://doi.org/10.1371/journal.pone.0138996

Lorenzoni, I., Nicholson-Cole, S., \& Whitmarsh, L. (2007). Barriers perceived to engaging with climate change among the UK public and their policy implications. Global Environmental Change, 17(3-4), 445-459. https://doi.org/10.1016/j.gloenvcha.2007.01.004

Manikandan, S. (2011). Frequency distribution. Journal of pharmacology \& pharmacotherapeutics, 2(1), 54-56. https://doi.org/10.4103/0976-500X.77120

Marty, R., \& Yokochi, R. (2006). Water in the early earth. Reviews in Mineralogy \& Geochemistry, 62(1), 421-450. http://dx.doi.org/10.2138/rmg.2006.62.18

Nigatu, A. S., Asamoah, B. O., \& Kloos, H. (2014). Knowledge and perceptions about the health impact of climate change among health sciences students in Ethiopia: A cross-sectional study. BMC Public Health, 14(587), 1-10. https://doi.org/10.1186/1471-2458-14-587 
Ochieng, M. A., \& Koske, J. (2013). The level of climate change awareness and perception among primary school teachers in Kisumu Municipality, Kenya. International Journal of Humanities and Social Science, 3(21), 174-179.

Odjugo, P. A. O. (2010). General overview of climate change impacts in Nigeria. Journal of Human Ecology, 29(1), 47-55. https://doi.org/10.1080/09709274.2010.11906248

Ogden, N. H. (2017). Climate change and vector-borne diseases of public health significance. FEMS Microbiological Letters, 364(19), 1-8. https://doi.org/10.1093/femsle/fnx186

Ojomo, E., Elliott, M., Amjad, U., \& Bartram, J. (2015). Climate change preparedness: A knowledge and attitudes study in southern Nigeria. Environments, 2(4), 435-448. https://doi.org/10.3390/environments2040435

Olaniyi, O. A., Olutimehin, I. O., \& Funmilayo, O. A. (2019). Review of climate change and its effect on Nigeria ecosystem. International journal of Rural Development, Environment and Health Research, 3(3), 92-100. https://dx.doi.org/10.22161/ijreh.3.3.3

Orlove, B., Roncoli, C., Kabugo, M., \& Majugu, A. (2010). Indigenous climate knowledge in southern Uganda: The multiple components of a dynamic regional system. Climatic Change, 100, 243-265. https://doi.org/10.1007/s10584-009-9586-2

Oruonye, E. D. (2011). An assessment of the level of awareness of the effects of climate change among students of tertiary institutions in Jalingo Metropolis, Taraba State Nigeria. Journal of Geography and Regional Planning, 4(9), 513-517. https://doi.org/10.5897/JGRP.9000012

Parant, A., Pascual, A., \& Jugel, M. (2016). Raising students awareness to climate change: An illustration with binding communication. Environmental Behavior, 4(9), 339-353. https://doi.org/10.1177/0013916516629191

Paternoster, R., \& Bachman, R. D. (2018). Essentials of statistics for criminology and criminal justice. California, USA: Sage Publications Inc.

Rahman, M. S., Overgaard, H. J., Pientong, C., Mayxay, M., Ekalaksananan, T., Aromseree, S. ... Haque, U. (2021). Knowledge, attitudes, and practices on climate change and dengue in Lao People's Democratic Republic and Thailand. Environmental Research, 193(110509), 1-11. https://doi.org/10.1016/j.envres.2020.110509

Rahman, S. M. A., Tasmin, S., Uddin, M. K., Islam, M. T., \& Sujauddin, M. (2014). Climate change awareness among the high school students: Case study from a climate vulnerable country. International Journal of Built Environment \& Sustainability, 1(1), 18-26. https://doi.org/10.11113/ijbes.v1.n1.4

Ramos, M. M. A., Ramos, P. L., Neto, F. L., \& Barba, P. C. (2019). Using software R in research in occupational therapy. Brazilian Journal of Occupational Therapy, 27(1), 217-230. https://doi.org/10.4322/2526-8910.ctoCB1625

Shukla, R., Agarwal, A., Sachdeva, K., Kurths, J., \& Joshi, P. K. (2019). Climate change perception: An analysis of climate change and risk perceptions among farmer types of Indian Western Himalayas. Climatic Change, 152, 103-119. https://doi.org/10.1007/s10584-018-2314-z

Sulistyawati, S., Mulasari, S. A., \& Sukesi, T. W. (2018). Assessment of knowledge regarding climate change and health among adolescents in Yogyakarta, Indonesia. Journal of Environmental and Public Health, 2018(9716831), 1-7. https://doi.org/10.1155/2018/9716831

Sullivan, A., \& White, D. D. (2019). An assessment of public perceptions of climate change risk in three western U.S. cities. Weather, Climate, and Society, 11, 449-463. https://doi.org/10.1175/WCAS-D-18-0068.1

Sundblad, E., Biel, A., \& Gärling, T. (2009). Knowledge and confidence in knowledge about climate change among experts, journalists, politicians, and laypersons. Environmental Behavior, 41(2), 281-302. https://doi.org/10.1177/0013916508314998

The National Academies. (2008). Understanding and responding to climate change: Highlights of National Academies reports. Retrieved from https://www.preventionweb.net/publications/view/2276

Tobler C., Visschers, V. H. M., \& Siegrist, M. (2012). Consumers' knowledge about climate change. Climatic Change, 114, 189-209. https://doi.org/10.1007/s10584-011-0393-1

Tuna, F., Incekara, S., \& Tunç, S. (2011). Measuring high school students' knowledge about climate change: A case study from Istanbul. World Applied Science Journal, 15(2), 297-303.

Turhan, N. S. (2020). Karl Pearson's chi-square tests. Educational Research and Reviews, 15(9), 575-580. 
https://doi.org/10.5897/ERR2019.3817

UNFCCC (1992). United Nations Framework Convention on Climate Change. Article 1: Definitions. Retrieved from https://unfccc.int/resource/docs/convkp/conveng.pdf

Voyer, D., \& Voyer, S. D. (2014). Gender differences in scholastic achievement: A meta-analysis. Psychological Bulletin, 140(4), 1174-1204. http://dx.doi.org/10.1037/a0036620

Wei, J., Hansen, A., Zhang, Y., Li, H., Liu, Q., Sun, Y., \& Bi, P. (2014). Perception, attitude and behavior in relation to climate change: A survey among CDC health professionals in Shanxi province, China. Environmental Research, 134, 301-308. http://dx.doi.org/10.1016/j.envres.2014.08.006

Whitmarsh, L., \& Lorenzoni, I. (2010). Perceptions, behavior and communication of climate change. Wiley Interdisciplinary Reviews of Climate Change, 1(2), 158-161. https://doi.org/10.1002/wcc.7

Workman, J., \& Heyder, A. (2020). Gender achievement gaps: The role of social costs to trying hard in high school. Social Psychology of Education, 23, 1407-1427. https://doi.org/10.1007/s11218-020-09588-6

Xie, B., Brewer, M. B., Hayes, B. K., McDonald, R. I., \& Newell, B. R. (2019). Predicting climate change risk perception and willingness to act. Journal of Environmental Psychology, 65(101331), 1-11. https://doi.org/10.1016/j.jenvp.2019.101331

Yang, L., Liao, W., Liu, C., Zhang, N., Zhong, S., \& Huang, C. (2018). Associations between knowledge of the causes and perceived impacts of climate change: A cross-sectional survey of medical, public health and nursing students in universities in China. International Journal of Environmental Research and Public Health, 15(2650), 1-14. https://doi.org/10.3390/ijerph15122650

\section{Copyrights}

Copyright for this article is retained by the author(s), with first publication rights granted to the journal.

This is an open-access article distributed under the terms and conditions of the Creative Commons Attribution license (http://creativecommons.org/licenses/by/4.0/). 